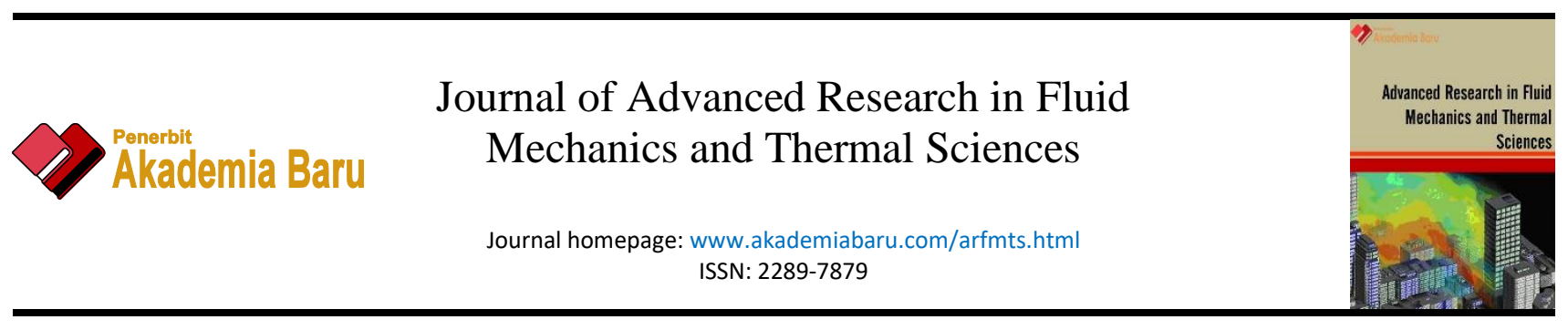

\title{
Selective Oxide Deposition on Fe-Based Alloys in Dry High Temperature Environment - A Review
}

\author{
Muhamad Hellmy Hussin ${ }^{1,}{ }^{*}$, Nur Azida Che Lah $^{1}$ \\ 1 Fabrication and Joining, University of Kuala Lumpur Malaysia France Institute (UNIKL MFI), Section 14, Jalan Teras Jernang, 43650, Bandar Baru \\ Bangi, Selangor, Malaysia
}

\section{ARTICLE INFO}

Article history:

Received 30 November 2019

Received in revised form 9 March 2020

Accepted 12 March 2020

Available online 30 June 2020

\section{ABSTRACT}

This paper presents a review of an investigation on selective deposition of oxides on Fe-based alloys in dry high temperature environment. The oxidation reaction occurred in order to promote a protective oxide layer to prevent corrosion attack and secure the metal substrate from degrade further. As temperature increased, the oxidation rate was significantly increased. Selective oxidation of an alloy component significantly lowers the concentration of that particular metal element in the alloy subsurface zones. As the cyclic thermal conditions increases, associated mechanical damage to the oxide scale leads to the porous oxide growth and also accelerates the depletion of alloy element. Eventually, prolong the process a point is reached where diffusion of anion to the alloy becomes competitive with the outward diffusion of metal cation to the developed protective scale. Selective oxidation changes the mechanical properties mainly due to the grain boundary oxidation. It is considered a short-path circuit for diffusion and hence leads to weaken the cohesive strength of individual grains. The focus of this work is to review the complex oxidation process due to the occurrence of selective oxidation and oxide deposition with the growth of oxide scale at different rates and also due to the presence of defects and clear microstructure differences of $\mathrm{Fe}$ - based alloys. It is also to enhance basic knowledge regarding the oxide layer behaviour that requires an understanding of alloy composition and microstructure. The consequences of oxide growth are specifically relative to the effects of factors such as exposure duration, temperature and operating parameters that must be clearly understood.

\section{Keywords:}

Fe-based alloys; oxidation; high temperature
Copyright @ 2020 PENERBIT AKADEMIA BARU - All rights reserved

\section{Introduction}

In high temperature service, oxidation becomes the most and prominent corrosion reaction in many industrial environments. In fact, metal alloys often rely on oxidation reaction in order to promote a protective oxide layer to prevent corrosion attack and secure the metal substrate from degrade further [1-3]. Common corrosion attack in high temperature service such as sulfidation,

\footnotetext{
* Corresponding author.

E-mail address: hellmy@unikl.edu.my
}

https://doi.org/10.37934/arfmts.72.2.2540 
carburization and ash or salt deposited corrosion. Generally, when Fe-based alloys exposed to high temperature corrosion or oxidation, the oxide scale formed in the temperature range of $370-560^{\circ} \mathrm{C}$ was mainly $\mathrm{Fe}_{2} \mathrm{O}_{3}$. As the temperature increased, the oxidation rate was significantly increased [4]. Particularly, the flow regimes of multiphase fluids or gases extremely have vital effects on the rate of corrosion. In high flow rates regimes, flow-induced corrosion and erosion-corrosion may occur.

Moreover, when the flow rates are low, typical type of pitting corrosion is more likely to occur. It is also related to the velocity amount and nature of sediment and definitely contaminants and dirt from gas applied [5-8]. Instead of that, the combination of gases can greatly accelerate the metal corrosion. In addition to that, the metal surface structure or joint design may become interest part providing sites for corrosion to occur. Importantly, these factors should be taken into account in order to inhibit the internal corrosion degradation and provide adequate method in preventing any accidents and unplanned shutdown [9-12]. Typically, the unplanned shutdown or plant breakdown appeared when involved catastrophic mechanical failures. Initially, when Fe - based alloys especially in piping or structure exposed to high temperature oxidation it provides a clearer and more complex implication [13]. This is because each alloying element in metal composition has different affinity to oxygen, which promotes the formation of different free-energy metals, producing more complex oxide compounds, solid solubility rates between different oxides, the presence of metal ions have different mobility and diffusion, and also include oxygen dissipation which results in sub-surface precipitation involving internal oxidation [14-15]. Based on these factors, the problem associated with oxidation for Fe - based alloys should be given an emphasis in this study. Therefore, high temperature corrosion for Fe - based alloys structure or piping in contact with oxidation become a dominant technology problem and to overcome it, is a challenge that needs to be addressed perfectly.

In this study, the focus is aimed to review the oxidation process which is more complex due to the occurrence of selective oxidation with the growth of oxide scale at different rates and also due to the presence of defects and clear microstructure differences of Fe - based alloys [16-20]. More complex conditions occur when it involves the oxidation of a metal in which the metal itself has different phase changes, composition, microstructure, and presence of defects that contribute to the reduction of performance. Factors such as design, the difference in chemicals and heat treatment plays a critical role in which it can affect the quality of the metal.

\section{High Temperature Oxidation in Fe-based Alloys}

Oxidation involving $\mathrm{Fe}$ - based alloys structures is a common problem faced by various industries. This is because the metal has undergone solidification and transformation in solid state, having an uneven surface, composition, structure and geometry that differ from base metal parts. Oxidation of the metal substrate produces a thin layer of oxide layers that encloses the entire surface of the substrate [21]. This involves a series of oxidizing mechanisms such as transporting or migrating oxygen molecules by physical adsorption to metal surfaces, chemical absorption, nucleation and oxide growth. In several types of chemical bonding usually it involves electron donation and acceptance especially during oxidation. Mostly metal oxides, sulphides etc. shows to have ionic bonding and has definite crystallographic structure where distributions of anions and cations was found at different distinct locations. As well discussed earlier, oxides usually consist of grains like metals, in crystallize condition, appear in grain growth. Basically, when it exposed to high temperature, the oxide itself may plastically damage and deformed and at high temperature it may plastically deformed [22]. 
Commonly, metal oxides present good conductivity properties and falls under semiconductors class category. It means that their conductivity falls between the insulators and metallic conductors [23]. This type of conductivity property increases with a slight shift from stoichiometric proportions of metal and oxygen. Generally, it happens when the temperature increased. Additionally, there are two types of semiconducting oxides which are; (i) p-type (positive carrier) and n-type (negative carrier). The p-type oxides include $\mathrm{Cu}_{2} \mathrm{O}, \mathrm{NiO}, \mathrm{FeO}, \mathrm{Cr}_{2} \mathrm{O}_{3}$ and $\mathrm{Fe}_{3} \mathrm{O}_{4}$. This type of oxides shift of stoichiometric proportions takes the form of a certain number of missing metal ions in the oxide lattice called cation vacancies [24-27]. It also maintains the electrical neutrality. The other type is $\mathrm{n}$ type oxides which includes $\mathrm{ZnO}, \mathrm{CdO}, \mathrm{TiO}_{2}, \mathrm{Al}_{2} \mathrm{O}_{3}$ and $\mathrm{Fe}_{2} \mathrm{O}_{3}$. For this type, excess of metal ions exist in interstitials positions of the oxide lattice. In addition to that, these metal ions suggested migrating with the electrons to the outer oxide surface during the oxidation takes place [28].

\section{Selective Oxide Layer Compound}

In many commercial production industries, the oxidation in environment containing free oxygen, carbon dioxide gases, water vapour and nitrogen takes place. Furthermore, the oxidation mechanism in ambient is definitely differs from that in a mixed-gas atmospheres [29-32]. On the other hand, when it involves metal alloys, it usually contains impurity elements and other added alloying elements. Each of the alloying elements presents different behaviour from each other. Typically, the presence of $\mathrm{Cr}, \mathrm{Al}$ and $\mathrm{Si}$ which definitely less noble than $\mathrm{Fe}$, contribute a certain level of oxidation resistance [33]. This would lead to insignificant protection effect because their levels are very low. Yanagihara et al., [34] reported peaks detection of $\mathrm{Fe}, \mathrm{FeSiO}_{4}$ and $\mathrm{FeO}$ was found on Fe-Si alloy annealed in atmosphere with a dew point of $71^{\circ} \mathrm{C}$ and having an oxygen potential higher than the equilibrium oxygen potential of the Fe-FeO system. It is demonstrated that the oxidation of Fe-Si alloy agrees very well with the prediction and confirmed the Si concentration was high according to the existence of $\mathrm{FeSiO}_{4}$. Presumably, the $\mathrm{FeSiO}_{4}$ phase detected was mainly in the internal oxidation zone [35].

Generally, when Fe oxidized, the familiar result observed is rust. The main compounds formed during reaction between $\mathrm{Fe}$ and oxygen when in contact with plenty of oxygen around. The compound form in Eq. (1) is called iron (II) oxide or ferrous oxide. This type of oxide is categorized under inorganic compound with the formula FeO. It is also known as wustite and presents in blackcolored powder [36]. Then, if Fe and oxygen are in contact at high enough temperatures, the iron (III) oxide, $\mathrm{Fe}_{2} \mathrm{O}_{3}$ formed and the common name is hematite. Hematite presents in grey or reddish compound as shown in Eq. (2). When Fe is heated in the presence of less oxygen, it is possible to synthesize to form another iron oxide, $\mathrm{Fe}_{3} \mathrm{O}_{4}$ called magnetite as shown in Eq. (3). The magnetite occurs in black color.

$$
\begin{aligned}
& 2 \mathrm{Fe}(\mathrm{s})+\mathrm{O}_{2}(\mathrm{~g}) \rightarrow 2 \mathrm{FeO}(\mathrm{s})-\text { wustite } \\
& 4 \mathrm{Fe}(\mathrm{s})+3 \mathrm{O}_{2}(\mathrm{~g}) \rightarrow \mathrm{Fe}_{2} \mathrm{O}_{3}(\mathrm{~s})-\text { hematite } \\
& 3 \mathrm{Fe}(\mathrm{s})+2 \mathrm{O}_{2}(\mathrm{~g}) \rightarrow \mathrm{Fe}_{3} \mathrm{O}_{4}(\mathrm{~s})-\text { magnetite }
\end{aligned}
$$

Basically, Iron oxides are possibly reduced by graphite during high temperature exposure. They revealed that the reduction of mass proved to present as an effect of the reduction of $\mathrm{Fe}_{3} \mathrm{O}_{4}$ and $\mathrm{Fe}_{2} \mathrm{O}_{3}$ to $\mathrm{Fe}$ and $\mathrm{FeO}$ [37]. The distinct reaction was presumably to be indirect reduction. It is mainly resulting from the reduction of nano-sized graphite with water that comprised in the argon gas. 
Larsson et al., [38] found after 1-hour exposure in dry oxygen at $600^{\circ} \mathrm{C}$, a thin layer of hematite deposition was dominated and covered, then become a thicker formation of magnetite layer on the surface of pure iron. Meanwhile, wustite formed at the interface between metal and oxide region. Besides, the oxide properties found on the pure iron revealed that after exposure to 1 and 3 hours, the porosity occurs and was found closely to the hematite interface. As for comparison, after 24 hours distribution the porosity was found more centered especially in the layer of magnetite. Marcius et al., [39] used Raman spectroscopy to show the presence of hematite in the outer oxide layer on iron plate exposed at 500 and $600^{\circ} \mathrm{C}$. They revealed that at low temperature of 300 and $400^{\circ} \mathrm{C}$ composed dominantly with magnetite and in a small fraction of hematite. Hisa et al., [32], Larsson et al., [38] and Marcius et al., [39] studied and revealed on the temperature and time dependence leads to different morphologies of iron oxide products. In addition to that, Marcius et al., [39] explained deeply on the hematite morphologies. They found that hematite particles present in elongated and very thin suggesting the shape of corn plant leaves. As temperature increased, the particle size increased perpendicular to their elongation [39-40].

As reported by Bertrand et al., [12], Grosvenor et al., [29], Larsson et al., [38] and Marcius et al., [39], the scale structure developed on Fe-alloys changes readily depending on the atmosphere and temperature, and most likely the result from structural change and scale formation was definitely found to affect the phase transformation behaviour of FeO. In addition to that, Kondo and Tanei [41] proved on the $\mathrm{FeO}$ phase transformation by oxidized the ultra-low carbon steel sheets in the furnace and held at $550^{\circ} \mathrm{C}$ or $700^{\circ} \mathrm{C}$ for $30 \mathrm{~min}$ to have a scale of different structures before phase transformation. He found that the bilayer scale of $\mathrm{Fe}_{3} \mathrm{O}_{4}$ and $\mathrm{FeO}$ transforms from the $\mathrm{Fe}_{3} \mathrm{O}_{4} / \mathrm{FeO}$ interface, while the monolayer scale of $\mathrm{FeO}$ alone generates $\mathrm{Fe}_{3} \mathrm{O}_{4}$ precipitates at the scale/steel interface preferentially. He also suggested that the phase transformation behaviour of FeO can be controlled by the initial scale structure. According to that, Kondo and Tanei [41] was found in agreement with Bertrand et al., [12], Grosvenor et al., [29], Larsson et al., [38] and Marcius et al., [39].

In the context of designing a corrosion resistance for components or structures, the fundamental aspect is basically depends on the formation of a slow-growing and protective oxide scale. It is developed mainly by selective oxidation of an appropriate alloy component [42,38]. Generally, selective oxidation process of an alloy component significantly lowers the concentration of that particular metal element in the alloy subsurface zones. As the cyclic thermal conditions increases, associated mechanical damage to the oxide scale leads to the porous oxide growth and also accelerates the depletion of alloy element [43-45]. Eventually, prolong the process; a point is reached where diffusion of anion to the alloy becomes competitive with the outward diffusion of metal cation to the developed protective scale. In high temperature environment with oxygen-rich atmospheres, resultant iron oxide scale which basically presented on the metal surface. As the oxidation prolong, it is sufficient to induce internal oxidation and it may proceed inside the grains and along the grain boundaries [46-49]. Selective oxidation changes the mechanical properties mainly due to the grain boundary oxidation. It is considered a short-path circuit for diffusion and hence leads to weaken the cohesive strength of individual grains. It is also influenced mainly by the temperature gradient that caused severe embrittlement.

In addition to that, Yuan et al., [50] discussed on the effect of Si content on different low carbon steels at heating temperature of $1260^{\circ} \mathrm{C}$. They found that Si appears to distribute in two distinct forms which are, (i) $\mathrm{Fe}_{2} \mathrm{SiO}_{4}$ (fayalite) where it takes place in the innermost region of the oxide scale, and (ii) granular $\mathrm{SiO}_{2}$ that was dispersively distributed mainly in the matrix closely near to the scale region. They reported that for steels with low $\mathrm{Si}$ content, less penetration of $\mathrm{Fe}_{2} \mathrm{SiO}_{4}$ specifically found along the grain boundary. This happens because it contains small amount of $\mathrm{Fe}_{2} \mathrm{SiO}_{4}$ and leads to the 
unnoticeable net-like pattern of $\mathrm{Fe}_{2} \mathrm{SiO}_{4}$. Meanwhile, for low carbon steel with $1.21 \mathrm{wt}$.\% $\mathrm{Si}$, the netlike pattern of $\mathrm{Fe}_{2} \mathrm{SiO}_{4}$ can be simply detected mainly in the innermost region of oxide scale which closely next to the Fe-matrix $[50,28]$.

\section{Oxide Layer Properties}

Alloy metal for high temperature applications depends on the construction and development of protective oxide layer formation to prevent high temperature effects. A good protective oxide layer has properties such as growing and formed at a steady rate and having a strong adhesion. Most of the metal alloys used in high temperature applications maintain resistance to high temperature corrosion by producing a protective oxide layer composed of alumina layers $\left(\mathrm{Al}_{2} \mathrm{O}_{3}\right)$, chromia $\left(\mathrm{Cr}_{2} \mathrm{O}_{3}\right)$ and silica $\left(\mathrm{SiO}_{2}\right)$ or spinel [51-54].

The oxide growth at temperature between 150 and $350^{\circ} \mathrm{C}$ could be described to have a homogenous and planar FeO layer. At this temperature Fe cations act as moving species during oxide growth and the oxidation rate is limited. Thin oxide films enough to cause interference colours until the film thickness reaches about $3 \times 10-6 \mathrm{~cm}$ and at the inital stage, it is invisible to ordinary observation [55]. Abuluwefa [1] performed an experiment for carbon steels samples and it shows that oxidation that occurs at lower temperature presents approximately a linear type of oxidation especially at temperature of $1000^{\circ} \mathrm{C}$. It shows the result of the controlling mechanism of oxidation. Yet, since it was a very thin oxide layer without any resistance barrier for oxygen/iron ion transportation to the reaction surface, hence it is exhibited a linear behavior $[56,1]$.

Meanwhile, it differs when compared to porous oxide scale growth. Prolong the time of exposure to certain temperature, oxide layer undergone thickening process. Thicker oxide layers with thickness more than $3000 \AA$ are called scales and its porous behaviour does not act to prevent access of oxygen to the metal surface. It usually composed of several layers of different oxides and commonly above $566{ }^{\circ} \mathrm{C}$, Fe-scales consists of three layers which are (i) FeO developed adjacent to steel base metal, (ii) $\mathrm{Fe}_{3} \mathrm{O}_{4}$ located in the middle layer and (iii) $\mathrm{Fe}_{2} \mathrm{O}_{3}$ that found on the top of surface layer [57-60]. It has been known that oxide scale on steel surface often detaches from the base metal during high temperature process. The detached and swelling oxide scale condition is called blistering. Blistering is one of the surface oxide scale defects that usually found during hot rolling process and it is occurred because of the growth stress due to scale formation. Hwan Bak et al., [36] reported that unprotective oxide scale developed on Fe-2\%Mn- $0.5 \% \mathrm{Si}-0.2 \%$ welded joint was found to be thicker on the outer scale compared to the inner scale. The rough and thick oxide scale was found susceptible to cracking and detached off from the inner mixed scale due to the large compressive stress developed. They found that the oxide scale was quite thick, brittle, cracked and could detach easily [61].

As reported by Dulgosch et al., [62] the low-carbon steel nanowire samples with thickness of $200 \mu \mathrm{m}$ were subjected to an oxidation in ambient air for $0.5-2$ hours at temperatures of $300^{\circ} \mathrm{C}-$ $700^{\circ} \mathrm{C}$. At initial state at $300^{\circ} \mathrm{C}$, no significant changes and oxide layer was clearly homogeneous. Furthermore, it shows an increase to $500^{\circ} \mathrm{C}$ for 2 hours and significantly enhances the number of hematite nanowires. As it reached $600^{\circ} \mathrm{C}$, elongated and dense coverage with dominations of nanowires and nanoflakes is distinctly detected. It is indicated that at $700^{\circ} \mathrm{C}$ the well-known top hematite layer. Meanwhile, the underneath layer of magnetite is visibly detectable in the form of floral-like arrangements of nanowires. In addition, the top layer of hematite occurs in the presence of porous network. It can be said that the growth of nano-crystalline iron-oxide indicates the influence of oxidation temperature [62-63].

It is not in agreement with Hwan Bak et al., [36] and as reported by Abuluwefa [1] the higher values of carbon content lead to the lower overall oxidation behaviour of steel, especially when 
exposed to high temperatures. He suggested that in higher levels of free oxygen atmospheres, development of oxide layers which comprised of three phases, mainly wustite $\mathrm{FeO}$, magnetite $\mathrm{Fe} 3 \mathrm{O} 4$ and a very small layer of hematite $\mathrm{Fe}_{2} \mathrm{O}_{3}$ was clearly dominated as the oxide products. It is suggested that to control scaling rates of the carbon steels, it is required to control the level of free oxygens in the furnace atmosphere. Instead of Abuluwefa [1], Suarez et al., [64] and Dulgosch et al., [62], Trindade et al., [65] also stated the similar findings on the possible phases formed. They stated that at $550^{\circ} \mathrm{C}$, in the region of higher oxygen potential the oxides formed $\mathrm{Fe}-\mathrm{Cr}-\mathrm{O}$ are hematite $\left(\mathrm{Fe}_{2} \mathrm{O}_{3}\right)$ and chromia $\left(\mathrm{Cr}_{2} \mathrm{O}_{3}\right)$. Meanwhile, for lower oxygen potentials, oxide products such as magnetite $\left(\mathrm{Fe}_{3} \mathrm{O}_{4}\right)$ and spinel $\left(\mathrm{FeCr}_{2} \mathrm{O}_{4}\right)$ are distinctly formed. Oxide product like Wustite (FeO) is not expected to occur since it is not stable below $570^{\circ} \mathrm{C}$. They confirmed the scale composed of a coarse-grained outer scale $\left(\mathrm{Fe}_{2} \mathrm{O}_{3}+\mathrm{Fe}_{3} \mathrm{O}_{4}\right)$, and it appears to grow by outward iron diffusion. For development of a fine-grained porous inner scale, it was found that the growth was dominated by inward oxygen diffusion $\left(\mathrm{Fe}_{3} \mathrm{O}_{4}+\mathrm{FeCr}_{2} \mathrm{O}_{4}\right)$ [65-68].

As compared to those observed by Kondo and Tanei [41], Yates et al., [71], Yanagihara et al., [34] and Yu et al., [69] observed more on the microstructure and morphologies of oxide growth on the typical steel substrate as indicated in Figure 1. As shown in Figure 1(a) and (b) Electron backscattered diffraction (EBSD) phase mapping showing a columnar-shape microstructure at the region between the outer granular grains and the globular inner layers. They found that the oxide scale developed consisted of a thin outer layer of hematite $\left(\mathrm{Fe}_{2} \mathrm{O}_{3}\right)$ and the inner duplex magnetite $\left(\mathrm{Fe}_{3} \mathrm{O}_{4}\right)$ layers $[69,71-74]$. It is confirmed by EBSD that the outer layer is existed in columnar structure, while the inner layer is much finer grained and the grains appears in equiaxed. Moreover, the grains of magnetite show to have granular shape with the size around $3 \mu \mathrm{m}$ and mostly found in the outer layer of oxide scale. In addition to that, hematite was found closely to the surface and gradually penetrates into the cracks within the oxide scale. Yu et al., [69] indicates some differences compared to the other studies and they detailed out the shape and the sequence of the oxide outer and inner layer developed on the steel substrate. It shows that the diffusion of metal ions which can leads into vacancies and cavity, in order to facilitate the local pores formation [69-75]. They found that the grain-refined metal substrate possibly can increase the grain boundary diffusion specifically at high temperature.

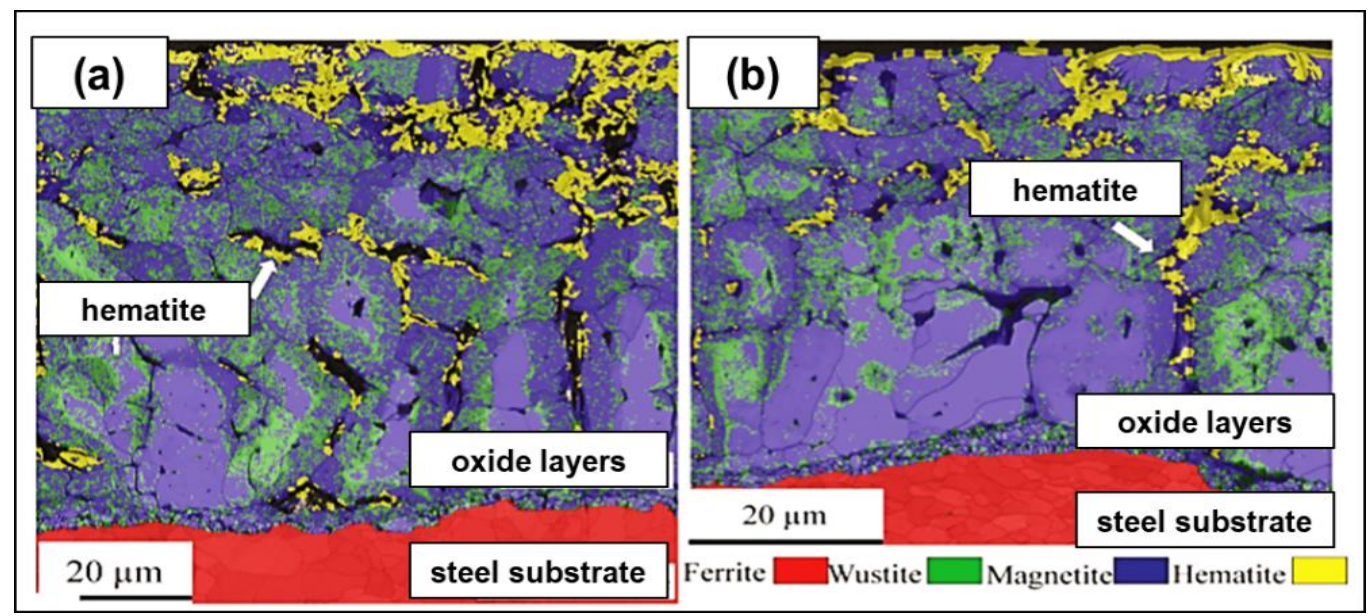

Fig. 1. Phase maps using EBSD of the microalloyed steel at $860^{\circ} \mathrm{C}$ and then cooling rates of (a) $10 \%, 10^{\circ} \mathrm{C} / \mathrm{s}$, and (b) $13 \%, 23^{\circ} \mathrm{C} / \mathrm{s}$ [69]

Yuan et al., [50] discussed the oxide growth of nanowire by the stress-drive mechanism. Although it is still remains in unclear grey area on how the compressive stress is generally developed in the 
oxide layer, but the volume difference between metal and oxides simply shows clear reflection especially in the development of scale thickness. As indicated in Figure 2, since wustite (FeO) does not form below $570^{\circ} \mathrm{C}$, therefore Fe oxidized below this temperature and is expected to form a twolayer structure of $\mathrm{Fe}_{3} \mathrm{O}_{4}$ (magnetite) and $\mathrm{Fe}_{2} \mathrm{O}_{3}$ (hematite) with $\mathrm{Fe}_{3} \mathrm{O}_{4}$ next to the Fe substrate [7680]. When the temperature reached above $570^{\circ} \mathrm{C}$, the oxide layer sequence is $\mathrm{FeO}, \mathrm{Fe}_{3} \mathrm{O}_{4}$ and $\mathrm{Fe}_{2} \mathrm{O}_{3}$ with the FeO layer developed next to Fe. According to the Figure 2, mechanism of gas oxygen diffusion into the oxide lattice during growth of oxide was first explained by chemisorption process on the $\mathrm{Fe}_{2} \mathrm{O}_{3}$ surface and definitely by attracting an electron from a Fe lattice site, and thus forming an electron hole. Then, the fully ionized chemisorbed oxygen forming another hole and a $\mathrm{Fe}^{3+}$ ion enters the surface to find the $\mathrm{O}^{2-}$ partner [81-83]. Therefore, another hole and vacancy formed mainly in the cation sub-lattice location. Subsequently, Fe cation vacancies and electron holes are distinctly created at the $\mathrm{Fe}_{2} \mathrm{O}_{3}$ surface. Following the process, this stage occurs when $\mathrm{O}_{2}$ at $\mathrm{Fe}_{2} \mathrm{O}_{3}$ surface utilized $\mathrm{Fe}^{3+}$ ions from the outer $\mathrm{Fe}_{2} \mathrm{O}_{3}$ lattice in order to form new $\mathrm{Fe}_{2} \mathrm{O}_{3}$ molecules [84].

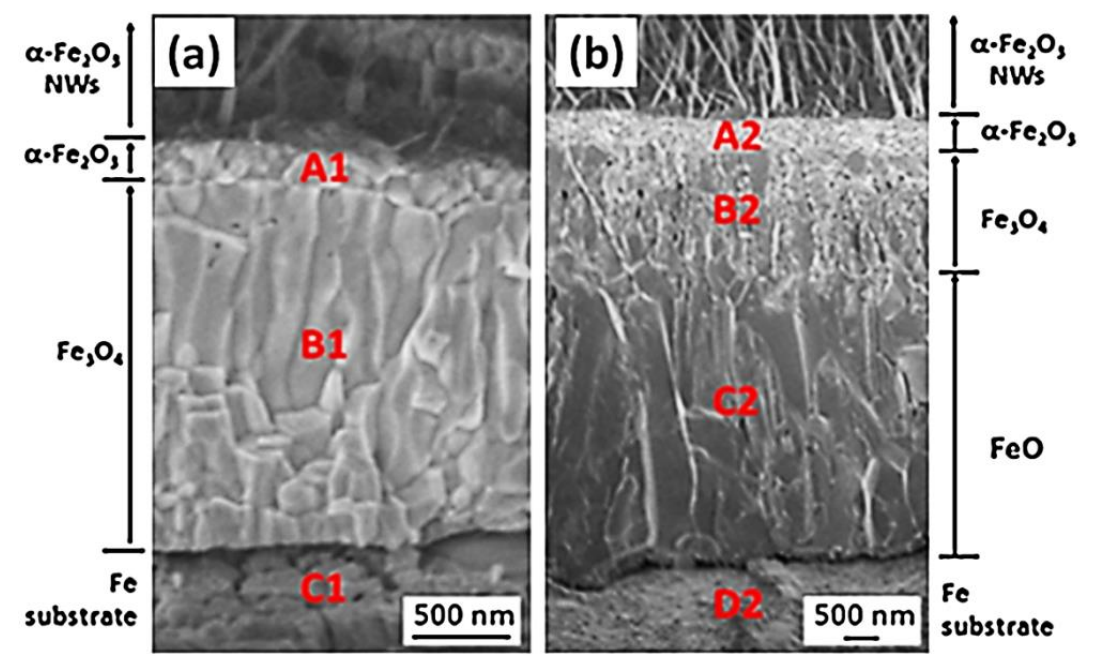

Fig. 2. SEM cross-sectional microstructural images of Fe substrates exposed to oxidation at (a) $400^{\circ} \mathrm{C}$ and (b) $600^{\circ} \mathrm{C}$ [70]

As reported by Hwan Bak et al., [36] and Yuan et al., [50], they were in agreement with Yuan et al., [70]. Yuan et al., [70] stated that the Pilling-Bedworth ration (PBR) of Fe oxide or Si oxide is more than 1 and was found at a temperature of $1260^{\circ} \mathrm{C}$. As the low carbon steel with different content of Si were heated at $1260^{\circ} \mathrm{C}$. The results show that the PBR is greater than 1 , and this happens because the volume of oxide is larger than that of the consumed metal and thus leads to a compressive stress in the oxide. This also related with the pressure difference in the liquefied $\mathrm{Fe}_{2} \mathrm{SiO}_{4}$ phase at $1260^{\circ} \mathrm{C}$, which shows a part of $\mathrm{Fe}_{2} \mathrm{SiO}_{4}$ that permeate into the inner scale. It was predicted that the liquid $\mathrm{Fe}_{2} \mathrm{SiO}_{4}$ phase distributes along the $\mathrm{FeO}$ grain boundary and the net-like $\mathrm{Fe}_{2} \mathrm{SiO}_{4}$ phase forms after its solidification. They also suggested that a larger compressive stress due to more $\mathrm{Fe}_{2} \mathrm{SiO}_{4}$ in steels with a higher Si content. This resulted in a deeper penetration layer [70,85-88].

Instead of Yuan et al., [70], Birosca et al., [14] explained that the oxide scale developed on low carbon steel after exposed to high temperature environment in free flowing air is however is not straightforward. As shown in Figure 3(a) wustite presence in dark colour relative to the magnetite and haematite where appeared in the lightest area. They also found that the wustite grain size increases with increasing temperature, causing grain and grain boundaries number to decrease with increasing temperature. In addition, they observed that the cracks and porosity may have a considerable effect on oxide grain shapes [89]. 


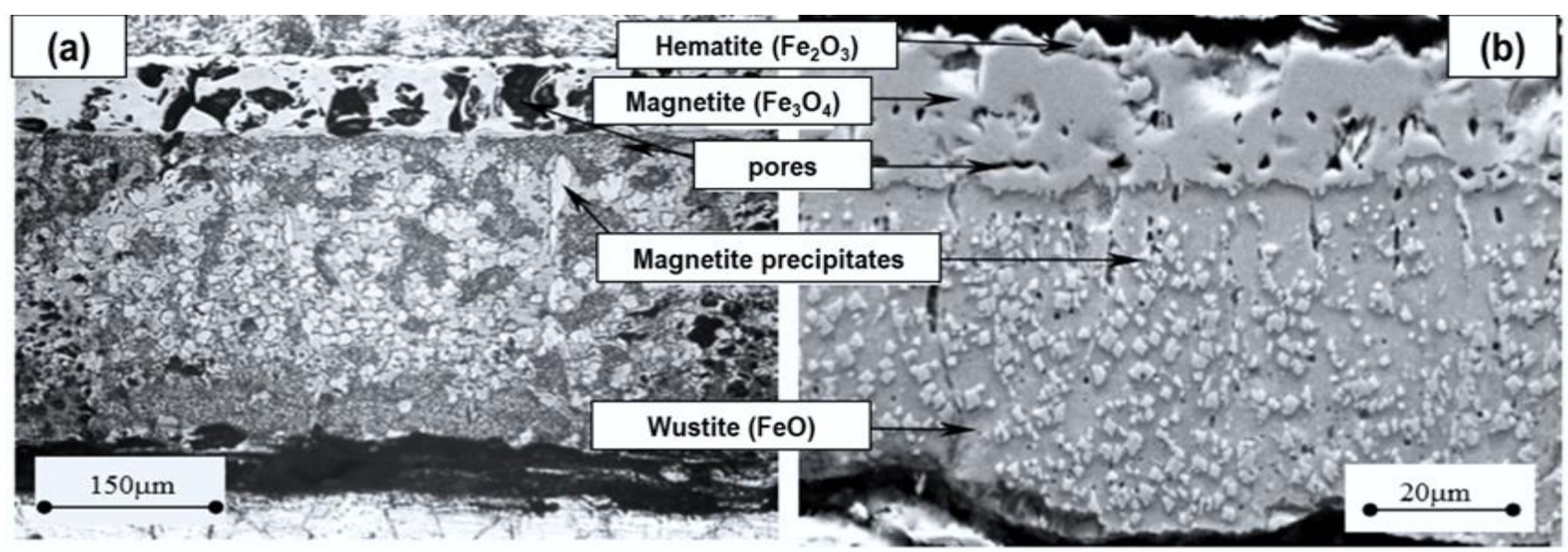

Fig. 3. Oxide scale developed on low carbon steel etched with $1 \% \mathrm{HCL}$ and ethanol, (a) optical micrograph at $1100^{\circ} \mathrm{C}$ for $1200 \mathrm{sec}$, and (b) SEM image at $900^{\circ} \mathrm{C}$ for $1800 \mathrm{sec}$ [14]

\section{Oxidation Mechanism on Iron Alloys}

These sections focused on a brief discussion on the oxidation mechanism that related to the previous work which involved Fe-based metal and Fe-alloys. Suggested and proposed mechanism were discussed and explained clearly in order to understand how the oxidation process takes place. As indicated in Figure 4 Suarez et al., [64], they show the scale growth mechanism under controlled and uncontrolled condition. It shows that at short oxidation times, the scale layer is not uniform and adherent. In all cases it is confirmed that wustite is the major oxide layer constituent.

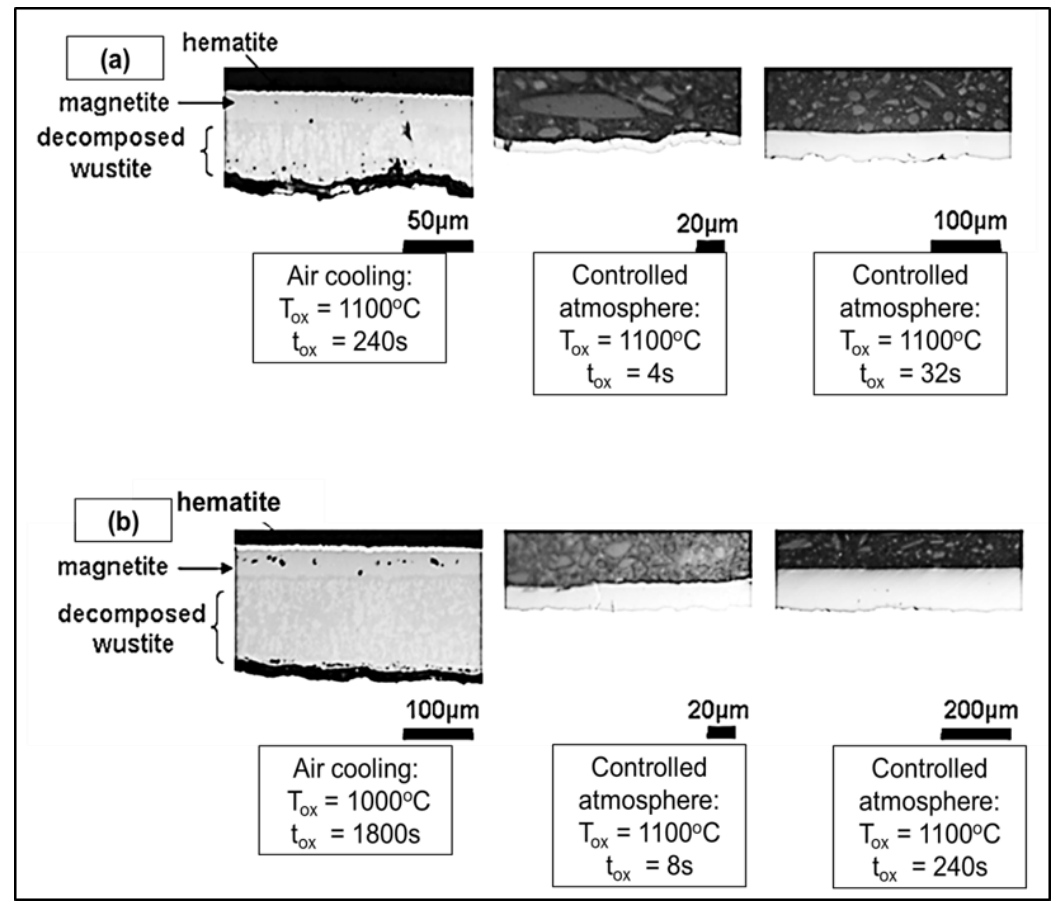

Fig. 4. Cross sections of oxide scale ultra low-carbon steels examined by OM in controlled and uncontrolled condition [64]

Yanagihara et al., [34] illustrates the change of surface structure of Fe-Si alloy due to oxidation. Internal oxidation takes place depends on the solute element due to its outward diffusion and oxygen due to inward diffusion. In the situation where oxygen potential is low, external oxidation becomes predominant. They proposed an illustration of Fe-Si alloy surface covered by $\mathrm{SiO}_{2}$ films by more than 
a certain proportion at the initial stage of oxidation [90-94]. In addition, internal oxidation in such portion is supressed in later stage. Hence, external oxidation only will advance locally while internal oxidation will take place in other parts as shown in Figure 5(a).

In comparison as shown in Figure 5(b), when the oxygen potential of the atmosphere is high, $\mathrm{Si}$ forms fine external and internal oxides at an early stage of oxidation and $\mathrm{SiO}_{2}$ does not form on the surface. Eventually, internal oxidation will advance thereafter homogenously in the depth direction. It can be said that, the higher the oxygen potential of the atmosphere, the larger the amount of internal oxides becomes. As shown in Figure 6 internal oxides content was larger in sample B compared to sample A. Instead of that, surface of sample B was smoother than sample A. As proposed by Yates et al., [71] it is suggested that alloying element and temperature dependance in Kovar plays an important role in determining the oxide layer properties as shown in Figure 6 . The layered oxide structure appears to compose of $\left(\mathrm{Co}, \mathrm{Fe}, \mathrm{Ni}_{3} \mathrm{O}_{4}\right.$ with varying ratios and $\mathrm{Fe}_{2} \mathrm{O}_{3}$. They confirmed using Raman spectroscopy and XRD that the first top layer initally to consist of $\mathrm{CoFe}_{2} \mathrm{O}_{4}$. The second layer shows to have the lowest $\mathrm{Fe}: \mathrm{O}$ ratio and it is suggested to compose of $\mathrm{Fe}_{2} \mathrm{O}_{3}$. It is thought the third layer to be a $(\mathrm{Fe}, \mathrm{Co})_{3} \mathrm{O}_{4}$ as confirmed by SEM, STEM and EDX with varying $\mathrm{Co}$ content but without $\mathrm{Ni}$ [95-96]. The fourth layer was found similar tot third layer but with addition of around 3 at. $\% \mathrm{Ni}$ and it is thought to be a $(\mathrm{Fe}, \mathrm{Co}, \mathrm{Ni})_{3} \mathrm{O}_{4}$ spinel. Then, followed by the fifth oxide layer is the region that is depleted in Fe and enriched in $\mathrm{Ni}$ and to a lesser extent $\mathrm{Co}$.

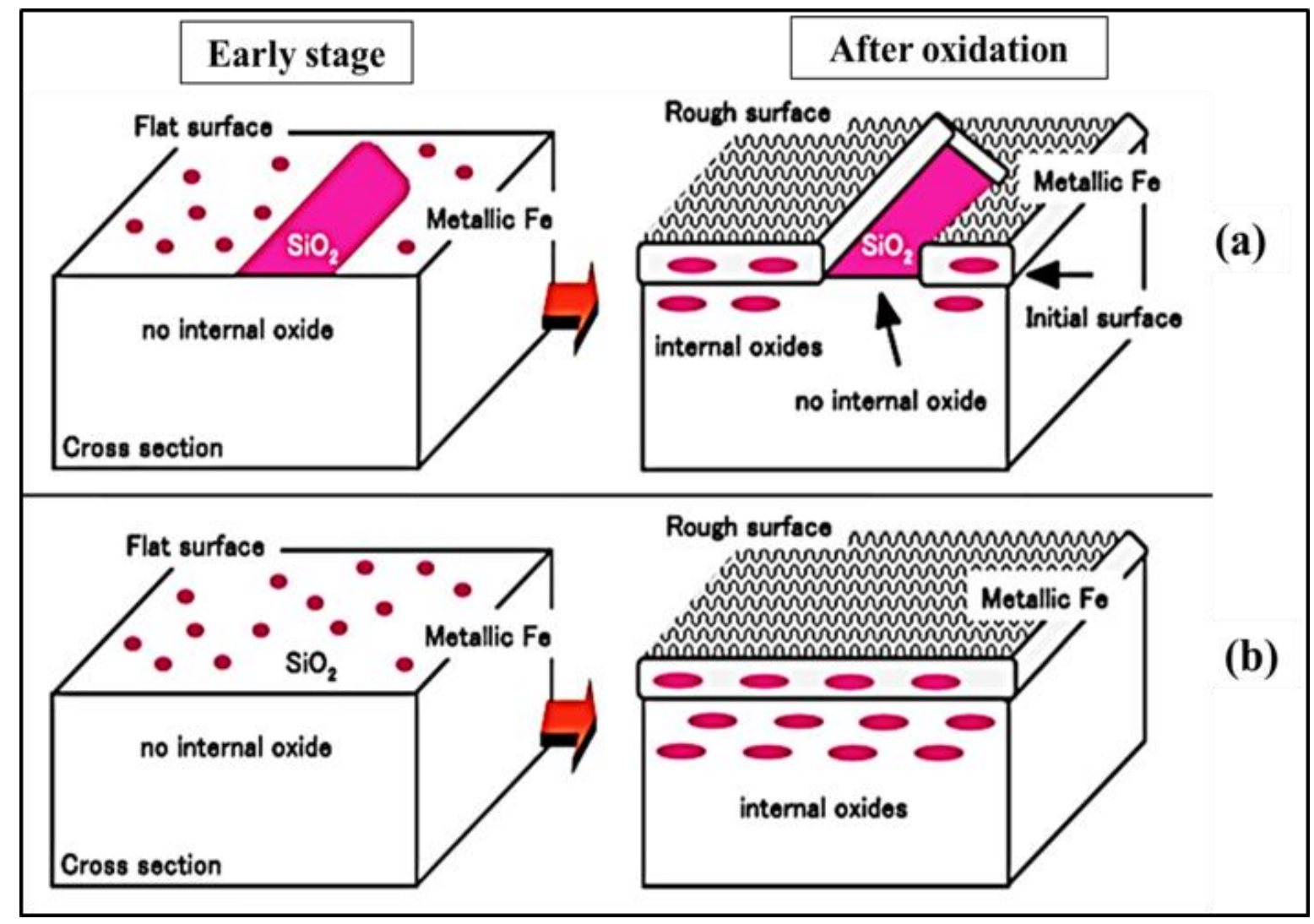

Fig. 5. Schematic surface structure of Fe-Si alloy samples, (a) A and (b) B caused by oxidation [34] 


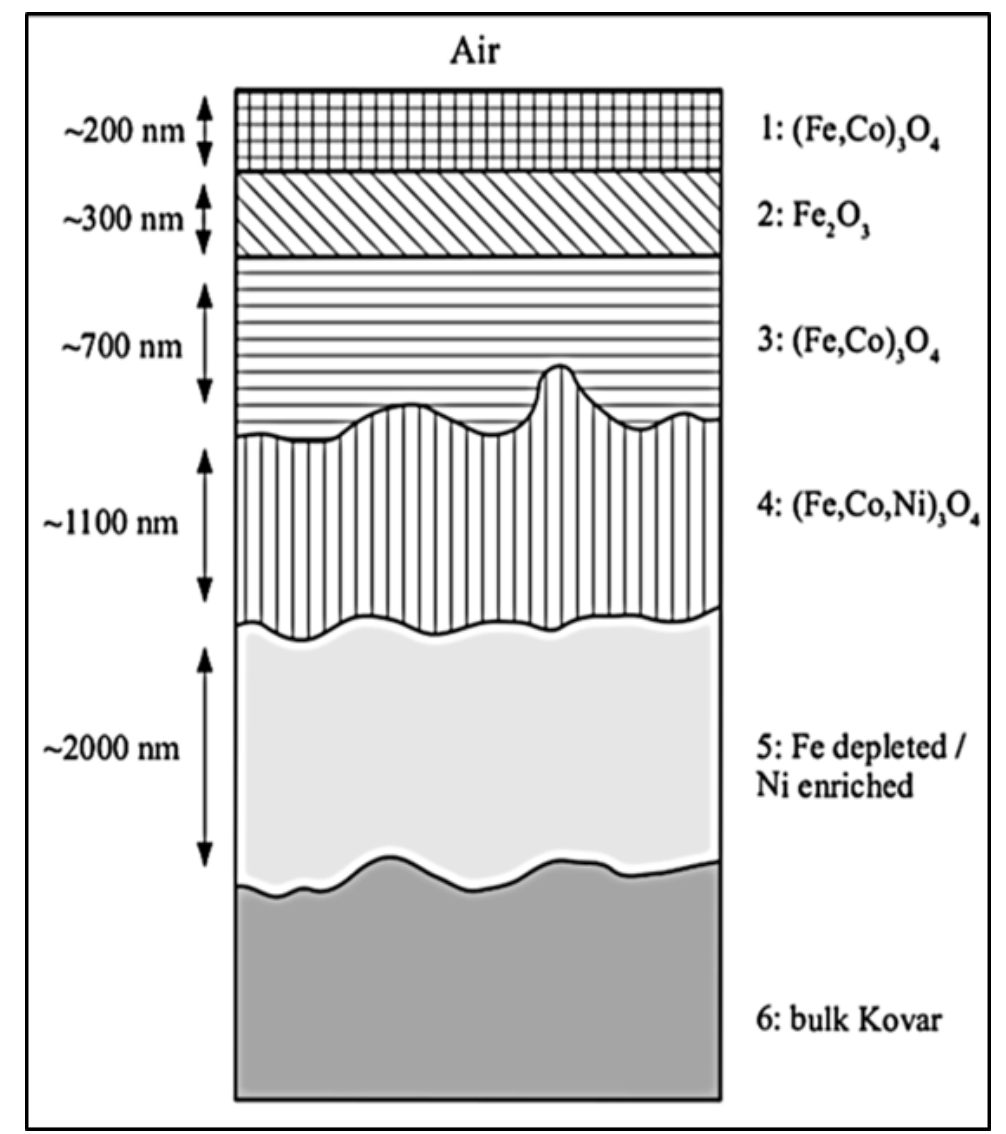

Fig. 6. The proposed structure of oxides developed on Kovar with approximate thickness grown at $700^{\circ} \mathrm{C}[71]$

Many studies have reported the phase transformation of FeO and as studied by Kondo and Tanei [41] the phase transformation of steel scale advances with $\mathrm{Fe}_{3} \mathrm{O}_{4}$ precipitating in the first place as shown in Figure 7. The $\mathrm{Fe}_{3} \mathrm{O}_{4}$ that precipitates at the beginning sometimes appears from interface between the base metal and $\mathrm{FeO}$ and this layer is called magnetite seam [97-98]. This transformation process oxidizing occurred at 700 to $750^{\circ} \mathrm{C}$, where the scale comprised of $\mathrm{FeO}, \mathrm{Fe}_{3} \mathrm{O}_{4}$ and $\mathrm{Fe}_{2} \mathrm{O}_{3}$. Meanwhile by holding at $550^{\circ} \mathrm{C}$ in $\mathrm{N}_{2}$ atmosphere, the $\mathrm{Fe}_{2} \mathrm{O}_{3}$ layer at the surface was changed into $\mathrm{Fe}_{3} \mathrm{O} 4$ and the scale comprised of two layers of $\mathrm{FeO}$ and $\mathrm{Fe}_{3} \mathrm{O}_{4}$. By holding at $700^{\circ} \mathrm{C}$, since $\mathrm{FeO}$ exist stably the $\mathrm{Fe}_{3} \mathrm{O}_{4}$ and $\mathrm{Fe}_{2} \mathrm{O}_{3}$ layers changed into a single $\mathrm{FeO}$ layer and thus the layer only comprised of one $\mathrm{FeO}$ layer. The two-layer (bilayer) scale made up of $\mathrm{FeO}$ and $\mathrm{Fe}_{3} \mathrm{O}_{4}$ and single-layer (monolayer) scale of FeO only obtained before phase transformation [41,99-101].

It is important to note that, issues in steel welded joint that reported recurrently by previous researchers mostly regarding to grain growth, embrittlement, grain boundaries carbides and sigma phase etc. Due to such problems, mechanical properties like toughness, ductility, high temperature strength and corrosion resistance is seriously affected and it would lead to abnormalities in phase present [102]. These difficulties have seriously affected the use of this economical material in many structures. Many researchers have contributed enormously to improve the weldability of ferritic stainless steel. Therefore, it is suggested that more special attention is required for the improvement of mechanical properties of steel and alloys during welding which have still some issues as well as its prevention method applied. 


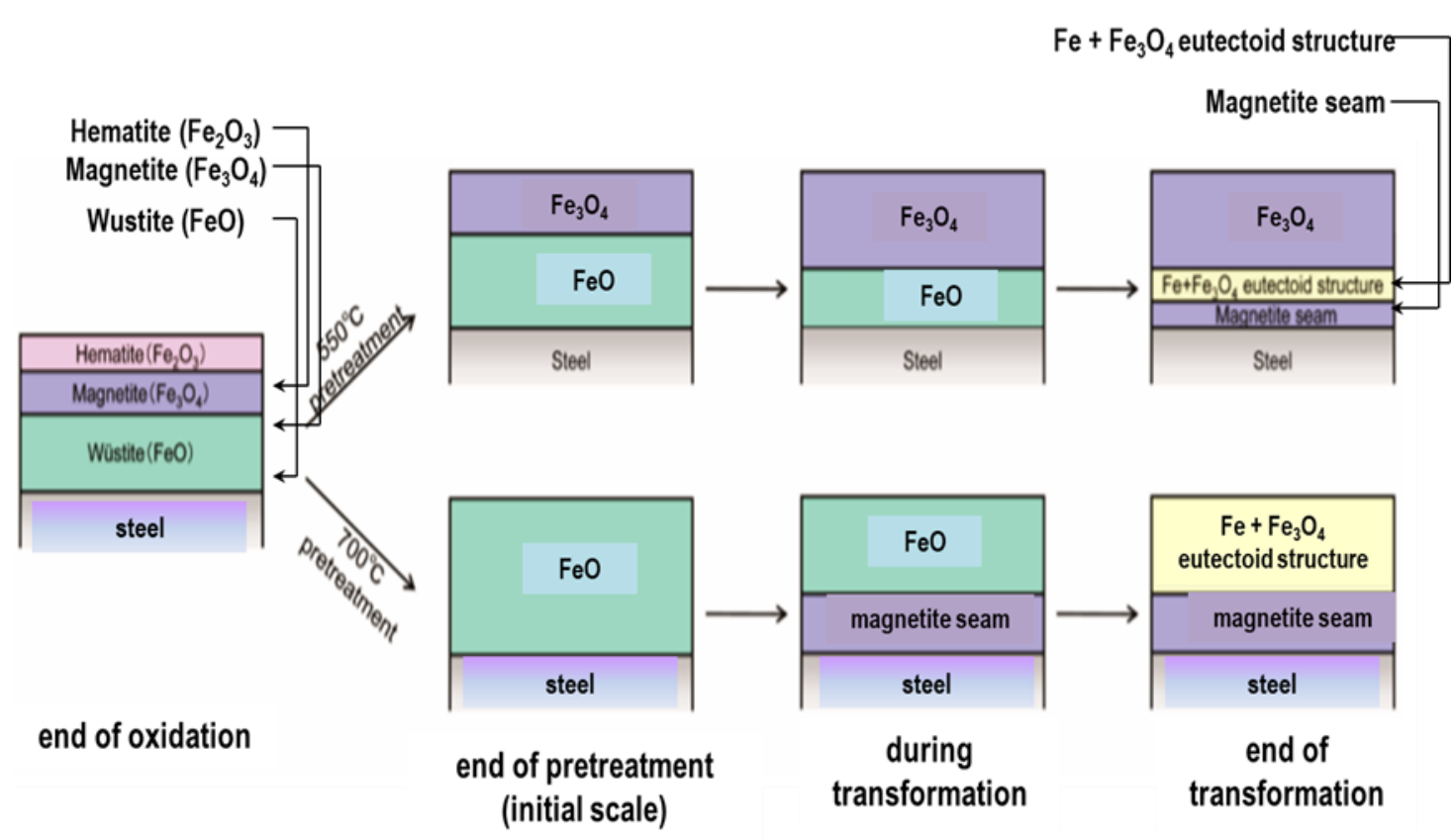

Fig. 7. The proposed structure of oxides developed on Kovar with approximate thickness grown at $700^{\circ} \mathrm{C}[71]$

\section{Conclusions}

In this review, previous study on selective deposition and development of oxide layer has been focused on Fe-based alloys. The main compounds formed during reaction between Fe and oxygen when in contact with plenty of oxygen around is $\mathrm{FeO}$. It is also known as wustite. Then, at high enough temperatures, the iron (III) oxide, $\mathrm{Fe}_{2} \mathrm{O}_{3}$ formed is hematite. Hematite presents in grey or reddish compound. When Fe is heated in the presence of less oxygen, it is possible to synthesize to form another iron oxide, $\mathrm{Fe}_{3} \mathrm{O}_{4}$ called magnetite and it occurs in black colour. Therefore, selective deposition that leads to an oxide phase transformation plays an important role in determining the oxide product characteristics. Future work needs to be done to measure and analyze the characteristics of each oxide products developed due to its heterogenous behavior in different oxidation environment and condition particularly at elevated temperatures.

\section{References}

[1] Abuluwefa, H. T. "Kinetics of high temperature oxidation of high carbon steels in multi-component gases approximating industrial steel reheat furnace atmospheres." Lecture notes in engineering and computer science (2012).

[2] Afoegba, S. C. "An investigation to improve the mechanical properties of A36 weldment." Pyrex Journal of Engineering and Manufacturing Technology 3, no.1 (2018): 1-9.

[3] Al-Saraireh, Falah Mustafa. "The effect of current and voltage on mechanical properties of low carbon steel products." International Journal of Mechanical Engineering and Technology (IJMET) 9, no. 3 (2018): 134-142.

[4] Alawadhi, Khaled, and M. J. Robinson. "Preferential weld corrosion of X65 pipeline steel in flowing brines containing carbon dioxide." Corrosion Engineering, Science and Technology 46, no. 4 (2011): 318-329. https://doi.org/10.1179/147842210X12695149033891

[5] Aloraier, Abdulkareem S., Suraj Joshi, Mahyar Asadi, Rubicel G. Alena, and John A. Goldak. "Microstructural and hardness modeling: Effect of multiple bead deposition in temper bead welding technique." International Journal of Energy and Technology 2, no. 16 (2010): 1-11.

[6] Arivazhagan, N., S. Narayanan, Surendra Singh, Satya Prakash, and G. M. Reddy. "High temperature corrosion studies on friction welded low alloy steel and stainless steel in air and molten salt environment at $650 \mathrm{C}$." Materials and Design 34 (2012): 459-468.

https://doi.org/10.1016/j.matdes.2011.08.034 
[7] Arslan, Ersin, Yaşar Totik, E. E. Demirci, Y. Vangolu, Akgün Alsaran, and I. Efeoglu. "High temperature wear behavior of aluminum oxide layers produced by AC micro arc oxidation." Surface and Coatings Technology 204, no. 6-7 (2009): 829-833. https://doi.org/10.1016/i.surfcoat.2009.09.057

[8] Asibeluo, I. S., and E. Emifoniye. "Effect of arc welding current on the mechanical properties of A36 carbon steel weld joints." SSRG International Journal of Mechanical Engineering 2, no. 9 (2015): 79-87.

[9] Atamuo, P. N., Gbasouzor Austin Ikechukwu, G. M. Onyegbuchule, and A. U. Iwuoha. "Warm Hydrocarbon Gas Flare Burners-Corrosion Analysis." In Proceedings of the World Congress on Engineering, vol. 3. 2013.

[10] Bakar, S. R. S., M. Y. Ahmad, Muhammad Faizol Ahmad Ibrahim, Azman Jalar, S. J. S. Djalil, and Norinsan Kamil Othman. "The effect of double pass GMAW process on microstructure and mechanical properties of AA 6061-T6 joining plates." In Key Engineering Materials, vol. 510, pp. 98-104. Trans Tech Publications Ltd, 2012. https://doi.org/10.4028/www.scientific.net/KEM.510-511.98

[11] Beck, A. F., M. A. Heine, E. J. Caule, and M. J. Pryor. "The kinetics of the oxidation of Al in oxygen at high temperature." Corrosion science 7, no. 1 (1967): 1-22.

https://doi.org/10.1016/S0010-938X(67)80066-0

[12] Bertrand, Nathalie, Clara Desgranges, Dominique Poquillon, Marie-Christine Lafont, and Daniel Monceau. "Iron oxidation at low temperature $(260-500 \mathrm{C})$ in air and the effect of water vapor." Oxidation of metals 73 , no. 1-2 (2010): 139-162. https://doi.org/10.1007/s11085-009-9171-0

[13] Bhattacharya, D. K. "Failures of welded joints." (1997): 212-220.

[14] Birosca, S., G. D. West, and R. L. Higginson. "Microstructural investigation of the oxide scale on low carbon steel." Metal 24, no. 26.5 (2005): 2005.

[15] Bodude, M. A., and I. Momohjimoh. "Studies on effects of welding parameters on the mechanical properties of welded low-carbon steel." Journal of Minerals and Materials Characterization and Engineering 3, no. 03 (2015): 142. https://doi.org/10.4236/immce.2015.33017

[16] Boumerzoug, Z., Derfour, C., and Baudin, T. "Effect of welding on microstructure and mechanical properties of an industrial low carbon steel." Engineering 2, (2010):502-506.

https://doi.org/10.4236/eng.2010.27066

[17] Britt, J. "All about Iron." Techno File (2011):14-15.

[18] Budiarto, Turnip, K., and Hantariksa. "The effect of current gouging arc welding analysis of A283 Gr C steel to the tensile strength, hardness and microstructure." In 2nd Nommensen International Conference on Technology and Engineering 420, (2018):1-8. https://doi.org/10.1088/1757-899X/420/1/012055

[19] Charde, Nachimani. "Effects of Electrode Deformation on Carbon Steel Weld Geometry of Resistance Spot Welding." Original Research Journal 1, no. 5 (2012): 5-12.

[20] Chevalier, S., C. Valot, G. Bonnet, J. C. Colson, and J. P. Larpin. "The reactive element effect on thermally grown chromia scale residual stress." Materials Science and Engineering: A 343, no. 1-2 (2003): 257-264.

https://doi.org/10.1016/S0921-5093(02)00359-3

[21] Devletian, J. H., and Heine, R. W. "Effect of Boron content on carbon steel welds." Welding Research Supplement 198 (1974): 45-53.

[22] Dhas, J. E. R., and Kumanan, S. "ANFIS for prediction of weld bead width in a submerged arc welding process." Journal of Scientific and Industrial Research 66,(2007): 335-338.

[23] Dlugosch, T., Chnani, A., Muralidhar, P., Schirmer, A., Biskupek, J., and Strehle, S. "Thermal oxidation synthesis of crystalline iron-oxide nanowires on low-cost steel substrates for solar water splitting." Semiconductor Science and Technology 32 (2017):(1-10). https://doi.org/10.1088/1361-6641/aa7593

[24] Doilnitsyna, V. V. "General diffusion-kinetic model of metallic oxidation." Corrosion Science 44 (2002):1113-1131. https://doi.org/10.1016/S0010-938X(01)00127-5

[25] Eliaz, N., Shemesh, G., and Latanision, R. M. "Hot corrosion in gas turbine components." Engineering Failure Analysis 9 (2002): 31-43. https://doi.org/10.1016/S1350-6307(00)00035-2

[26] Eskin, D. G., Massardier, V., and Merle, P. "A study of high-temperature precipitation in Al-Mg-Si alloys with an excess of silicon." Journal of Materials Science 34, no.4 (1999): 811-820. https://doi.org/10.1023/A:1004585216084

[27] Frolish, M. F., Krzyzanowski, M., Rainforth, W. M., and Beynon, J. H. "Oxide scale behaviour on aluminium and steel under hot working conditions." Journal of Materials Processing Technology 177 (2006): 36-40. 
https://doi.org/10.1016/j.jmatprotec.2006.03.224

[28] Garcia, M. P., Mantovani, G. L., Kumar, R. V, and Antunes, A. "Corrosion behavior of metal active gas welded joints of a high-strength steel for automotive application." Journal of Materials Engineering and Performance, (2017):115.

[29] Grosvenor, A. P., Kobe, B. A., and McIntyre, N. S. "Examination of the oxidation of iron by oxygen using X-ray photoelectron spectroscopy and QUASESTM." Surface Science 565 (2004): 151-162. https://doi.org/10.1016/i.susc.2004.06.210

[30] Gupta, S., Datla, S. V, Sekhar, C. P., and Sahreef, N. A. "An experimental investigation on A36 carbon steel in submerged arc welded joints." International Journal of Mechanical Engineering and Technology (IJMET) 9, no. 4(2018): 302-311.

[31] Hasan, M. F. "Analysis of Mechanical Behaviour and Microstructural Characteristics Change of ASTM A-36 Steel Applying Various Heat Treatment." Journal of Material Science and Engineering 5, no. 2 (2016): 1000227.

[32] Hisa, M., Tsutsumi, A., and Akiyama, T. "Reduction of iron oxides by nano-sized graphite particles observed in preoxidized iron carbode at temperature around 873K." Materials Transaction 45, no. 6 (2004): 1907-1910. https://doi.org/10.2320/matertrans.45.1907

[33] Holm, V. C. F. "Elimination of oxide films on ferrous materials by heating in vacuum." Journal of Research of the National Bureau of Standard (1942):569-579.

https://doi.org/10.6028/ires.028.022

[34] Yanagihara, K., and Yamazaki, S. "Characterization of oxidation behavior at Fe-Si alloy surface." Nippon Steel Technical Report (2011): 27-32.

[35] Hrabe, P., Choteborsky, R., and Navratilova, M. "Influence of welding parameters on geometry of weld deposit bead. " International Conference on Economic Engineering and Manufacturing Systems 10, no. 3 (2009): 1-4.

[36] Bak, S., Jung Kim, M., and Bok Lee, D. "High-temperature corrosion of weldment of Fe-2\% $\mathrm{Mn}-0.5 \% \mathrm{Si}$ steel in $\mathrm{N}_{2} / \mathrm{H}_{2} \mathrm{O} / \mathrm{H}_{2} \mathrm{~S}$-mixed gas." International Scholarly and Scientific Research and Innovation 10, no. 2 (2016): 167-172.

[37] Jalar, A., Lah, N. A. C., Othman, N. K., Shamsudin, R., Daud, A. R., and Bakar, S. R. S. "Characterization of oxide growth on surface of Al-Mg-Si welded joint." Advanced in Materials Science and Engineering (2014): 1-10. https://doi.org/10.1155/2014/272804

[38] Larsson, H., Jonsson, T., Naraghi, R., Gong, Y., Reed, R. C., and Agren, J. "Oxidation of iron at $600{ }^{\circ} \mathrm{C}$ - experiments and simulations." Materials and Corrosion 68 (2017): 133-142.

https://doi.org/10.1002/maco.201508781

[39] Marcius, M., Ristic, M., Ivanda, M., and Music, S. "Formation of iron oxides by surface oxidation of iron plate." Croatica Chemica Acta 85, no. 1 (2012): 117-124.

https://doi.org/10.5562/cca1943

[40] Jodia, W. M. "Study the change of current weld on mechanical properties and microstructure of low carbon steel welded by electric arc welding." Journal of Babylon University Engineering Sciences 25, no.4 (2017): 1470-1477.

[41] Kondo, Y., and Tanei, H. "Phase transformation of oxide scale and its control." Nippon Steel and Sumitomo Metal Technical Report no. 111 (2016): 87-91.

[42] John, R. C., Pelton, A. D., Young, A. L., Thompson, W. T., Wright, I. G., and Besmann, T. M. "Assessing corrosion in oil refining and petrochemical processing." Materials Research 7, no. 1 (2004): 163-173. https://doi.org/10.1590/S1516-14392004000100022

[43] Kalsi, S. S. "Hot corrosion and its mechanism : A review." International Journal on Emerging Technologies 7, no. 1 (2016), 133-136.

[44] Kamely, M. A., Bani Hashim, A. Y., Yahaya, S. H., Sihombing, H., and Hazman, H. "The effect of multipass cutting in grinding operation." International Journal of Mechanical, Aerospace, Industrial, Mechatronic and Manufacturing Engineering 7, no. 3 (2013): 508-511.

[45] Karlsson, L., Keehan, E., Andren, H. O., and Bhadeshia, H. K. D. H. "Development of high strength steel weld metals - Potential of novel high-Ni compositions." Eurojoin 5 (2004): 1-8.

[46] Keehan, E., Karlsson, L., and Andren, H. O. "Influence of carbon, manganese and nickel on microstructure and properties of strong steel weld metals. Part 1 - Effect of nickel content." Science and Technology of Welding and Joining 11 , no. 1 (2006): 1-8.

https://doi.org/10.1179/174329306X77830

[47] Khalid, N., Zamanhuri, P. Z. N. M., and Shaiful Baharin, F. A. "A study of weld defects of gas metal arc welding with different shielding gasses." ARPN Journal of Engineering and Applied Sciences 12, no. 6 (2017): 2006-2011.

[48] Klaric, S., Samardzic, I., and Kladaric, I. "MAG welding process - Analysis of welding parameter influence on joint geometry." In 12th International Research and Expert Conference (2008): 185-188.

[49] Kofstad, Per. "High temperature corrosion." Elsevier Applied Science Publishers, Crown House, Linton Road, Barking, Essex IG $118 \mathrm{JU}$, UK, 1988. (1988). 
[50] Yuan, Lu, Yiqian Wang, Rongsheng Cai, Qike Jiang, Jianbo Wang, Boquan Li, Anju Sharma, and Guangwen Zhou. "The origin of hematite nanowire growth during the thermal oxidation of iron." Materials Science and Engineering: B 177, no. 3 (2012): 327-336. https://doi.org/10.1016/i.mseb.2011.12.034

[51] Kolahan, F., and Heidari, M. "A new approach for predicting and optimizing weld bead geometry in GMAW." International Journal of Mechanical and Mechatronics Engineering 3, no. 11 (2009): 1391-1394.

[52] Kolawole, F. O., S. K. Kolawole, J. O. Agunsoye, J. A. Adebisi, S. A. Bello, and S. B. Hassan. "Mitigation of Corrosion Problems in API 5L Steel Pipeline-A Review." J. Mater. Environ. Sci 9, no. 0 (2018): 8.

[53] Kondo, Y., Suzuki, N., Maeda, M., Tanei, H., and Ushioda, K. "Blistering behaviour during oxide scale formation on steel surface." Nippon Steel and Sumitomo Metal Technical Report (2016):79-86.

[54] Kursun, T. "Effect of the GMAW and the GMAW-P welding processes on microstructure, hardness, tensile and impact strength of AISI 1030 steel, joints fabricated by ASP316L austenitic stainless steel filler metal." Archives of Metallurgy And Materials 56, no. 4 (2011): 956-963. https://doi.org/10.2478/v10172-011-0105-x

[55] Masanori, I., Kousuke, A., Tomo, T., and Eiichi, S. "Highly strong and conductive carbon nanotube/cellulose composite paper." Composites Science and Technology 70, no. 10 (2010): 1564-1570. https://doi.org/10.1016/i.compscitech.2010.05.023

[56] McAdam Jr, D. J., and Geil, G. W. "Rate of oxidation of steels as determined from interference colors of oxide films." Journal of Research of the National Bureau of Standard 23 (1939): 63-124. https://doi.org/10.6028/ires.023.041

[57] Melchers, R. E. "A review of trends for corrosio loss and pit depth in longer-term exposures." Corrosion and Materials Degradation 1 (2018): 42-58. https://doi.org/10.3390/cmd1010004

[58] Mobin, M., and Hasan, S. K. "Chemical interaction of ferric oxide with sodium sulfate at high temperature relevant to hot corrosion." Journal Materials Environment Science 3, no. 1 (2012): 109-116.

[59] Muhamad Hellmy, H., and Nur Azida, C. L. "Cross-sectional analysis of oxidized fusion zone of welded AA6061 Al alloy at high temperature." In 3rd Internation Conference on Advanced Manufacturing (ICAM 2016), (2016): 6-10.

[60] Muhamad Hellmy, H., and Nur Azida, C. L. "An X-ray Photoelectron Spectroscopy Study On Oxidized Fusion Metal Part Of Welded 6061 Al Alloy." Jurnal Teknologi 79, no. 1 (2017): 1-17. https://doi.org/10.11113/it.v79.7648

[61] Murariu, A. C., and Plesu, N. "Investigation on corrosion behaviour of welded joint in ASTM A355P5 alloy steel pipe." International Journal of Electrochemical Science 10 (2015): 10832-10846.

[62] Dlugosch, T., Chnani, A., Muralidhar, P., Schirmer, A., Biskupek, J., and Strehle, S. "Thermal oxidation synthesis of crystalline iron-oxide nanowires on low-cost steel substrates for solar water splitting." Semiconductor Science and Technology 32 (2017):1-10. https://doi.org/10.1088/1361-6641/aa7593

[63] Noguchi, M., and Yakuwa, H. "Lecture o fundamental aspects of high temperature corrosion and corrosion protection. Part 1: Basic theory." Ebara Engineering Review 10, no. 252 (2016): 1-11.

[64] Suarez, Lucia, R. Coto, X. Vanden Eynde, M. Lamberigts, and Yvan Houbaert. "High temperature oxidation of ultralow-carbon steel." In Defect and Diffusion Forum, vol. 258, pp. 158-163. Trans Tech Publications Ltd, 2006. https://doi.org/10.4028/www.scientific.net/DDF.258-260.158

[65] Trindade, V. B., Borin, R., Hanjari, B. Z., Yang, S., Krupp, U., and Christ, H. "High-temperature oxidation of pure Fe and the Ferritic steel 2.25Cr1Mo." Materials Research 8, no. 4 (2005): 365-369. https://doi.org/10.1590/S1516-14392005000400002

[66] Hamid, Nur Zarifah Abdul, Nor Fadzillah Mohd Mokhtar, Norihan Md Arifin, Mohammad Hasan, and Abdul Sathar. "Effect of Nonlinear Temperature Profile on Thermal Convection in a Binary Fluid Saturated an Anisotropic Porous Medium." Journal of Advanced Research in Fluid Mechanics and Thermal Sciences 56, no. 1 (2019): 43-58.

[67] Aldoori, W. H., and Ahmed, A. H. "The effect of varying tube diameters on enhancement heat transfer by forced convection through a horizontal tube." Journal of Advanced Research in Fluid Mechanics and Thermal Sciences 66, no. 1 (2020):179-188.

[68] Alias, Hajar, Adnan Hameed Rasheed, and Sami D. Salman. "Enhancement of Nanofluid Heat Transfer in Elliptical Pipe and Helical Micro Tube Heat Exchanger." Journal of Advanced Research in Fluid Mechanics and Thermal Sciences 66, no. 1 (2020): 53-63.

[69] Yu, X., and Zhou, J. "Grain boundary in oxide scale during high-temperature metal processing. " Intech Open (2016): 59-77. https://doi.org/10.5772/66211 
[70] Yuan, Q., Xu, G., Zhou, M., and He, B. "The effect of the Si content on the morphology and amount of Fe2SiO4 in Low carbon steels." Metals 6, no. 94 (2016): 1-9.

https://doi.org/10.3390/met6040094

[71] Yates, P. M., Mallinson, C. F., Mallinson, P. M., and Yeomans, J. A. "An investigation into the nature of the oxide layer formed on Kovar (Fe-29Ni-17Co) wires following oxidation in air at 700 and $800{ }^{\circ} \mathrm{C}$." Oxidation of Metals 88 (2017): 733-747. https://doi.org/10.1007/s11085-017-9772-y

[72] Bash, Adel Mahmoud. "Numerical Simulation of Welding Influence on Tensile Strength and Residual Stress of AISI 304 Butt Joints." Journal of Advanced Research in Fluid Mechanics and Thermal Sciences 64, no. 1 (2019): 77-91.

[73] Darmadi, Djarot B., Lingga P. Setiawan, and Shahruddin Mahzan. "Evaluating the GMAW Joint with a Constant Heat Input." Journal of Advanced Research in Fluid Mechanics and Thermal Sciences 54, no. 2 (2019): 142-149.

[74] Fung, Chang Kai, and Mohd Fadhil Majnis. "Computational Fluid Dynamic Simulation Analysis of Effect of Microchannel Geometry on Thermal and Hydraulic Performances of Micro Channel Heat Exchanger." Journal of Advanced Research in Fluid Mechanics and Thermal Sciences 62, no. 2 (2019): 198-208.

[75] Jumaidin, R., Jopri, I. F., Hasan, R., Hakimi Chua Abdullah, M. I., Firdaus Hussin, M. S., Aziz, A. R., Idral, F. "Effect of cooling medium and tempering on microstructures and hardness of SK3 high carbon steel." Journal of Advanced Research in Fluid Mechanics and Thermal Sciences 63, no. 2 (2019): 199-209.

[76] Kareem, Rabiha Saleem, and Ahmed M. Abdulhadi. "Effect of MHD and Porous Media on Nanofluid Flow with Heat Transfer: Numerical Treatment." Journal of Advanced Research in Fluid Mechanics and Thermal Sciences 63, no. 2 (2019): 317-328.

[77] Norfadhlina, K., Puteri Zirwatul Nadila, M. Z., and Faisal Ahmad, S. B. "A study of weld defects of gas metal arc welding with different shielding gasses." ARPN Journal of Engineering and Applied Sciences 12, no. 6 (2017):20062011.

[78] Nur Azhani, A. R., and Ng, S. S. "Investigation of effects of MIG welding on corrosion behaviour of AISI 1010 carbon steel." Journal of Mechanical Engineering and Science 7 (2014): 1168-1178. https://doi.org/10.15282/imes.7.2014.16.0114

[79] Palmer-Jones, R. "Repairing internal corrosion defects in pipeline." In 4th International Pipeline Rehabilitation and Mainternance Conference (2000): 1-25.

[80] Nor, Fazrul Mohd, and Abd Khamim Ismail Abd Rahman Tamuri. "New Development in Determination of Metal Volume Thermal Expansion Measurement Using Hydrostatic Weighing System (HWS)." Journal of Advanced Research in Fluid Mechanics and Thermal Sciences 58, no. 1 (2019): 78-83.

[81] Sukamta, and Sudarja. "Pressure gradient on gas-liquid two-phase flow with high viscosity in capillary pipe with the slope of 5 degrees of horizontal pipe." Journal of Advanced Research in Fluid Mechanics and Thermal Sciences 63, no. 2 (2019): 210-217. https://doi.org/10.37934/arfmts.69.2.120129

[82] Tanasta, Zaimi, Pauziah Muhamad, Noriyuki Kuwano, Mohd Hishamuddin Unuh, and Mohd Hafiz. "Effect of HighTemperature Annealing Heat Treatment to Microstructure of Aluminium Nitride on Sapphire Substrate." Journal of Advanced Research in Fluid Mechanics and Thermal Sciences 56, no. 2 (2019): 267-275.

[83] Parkinson, G. S. "Iron oxide surface." Surface Science Reports 71 (2016):272-365. https://doi.org/10.1016/i.surfrep.2016.02.001

[84] Pawar, S. S., and Inamdar, K. H. "Factors affecting quality of plasma arc cutting process: A review." International Journal of Advanced Technology in Engineering and Sciences 4, no. 2 (2016): 177-183.

[85] Potapov, N. N. "Oxygen effect on low-alloy steel weld metal properties." Welding Research Supplement (1993): 367-370.

[86] Rana, R. S., Purohit, R., and Das, S. "Reviews on the Influences of Alloying element on the microstructure and Mechanical properties of Aluminium Alloys and Aluminium Alloy composite." International Journal of Scientific and Research Publication 2, no. 6 (2012): 1-7.

[87] Ronqueti, L. A., Favergeon, J., Risbet, M., and Picard, M. "Study of grain boundary oxidation of high alloyed carbon steels at coiling temperature." In 53th Seminario de Laminacao (2016): 283-292.

https://doi.org/10.5151/1983-4764-27735

[88] Salonitis, Konstantinos. "On surface grind hardening induced residual stresses." (2014).

[89] Farhangdoost, Khalil. "Achieve to desired weld bead geometry for the vessel fillet joints in mobile robotic welding." In Tehran International Congress on Manufacturing Engineering-TICME2005. 2005.

[90] Shoeb, M., Parvez, M., and Kumari, P. "Effect of MIG welding input process parameters on weld bead geometry on HSLA steel." International Journal of Engineering Science and Technology 5, no. 1 (2013): 200-215.

[91] Silva, C. C., de Assis, J. T., Philippo, S., and Farias, J. P. "Residual stress, microstructure and hardness of thin-walled Loe-Carbon steel pipes welded manually." Materials Research 19, no. 6 (2016): 1215-1225. 
https://doi.org/10.1590/1980-5373-mr-2016-0217

[92] Sinebryukhov, S. L., Sodorova, M. V, Egorkin, V. S., Nedozorov, P. M., Ustinov, A. Y., Volkova, E. F., and Gnedenkov, S. V. "Protective oxide coatings on Mg-Mn-Ce, Mg-Zn-Zr, Mg-Al-Zn-Mn, Mg-Zn-Zr-Y, and Mg-Zr-Nd magnesiumbased alloys." Protection of Metals and Physical Chemistry of Surfaces 48, no. 6 (2012): 678-687. https://doi.org/10.1134/S2070205112060147

[93] Taie, I., Al-Shahrani, A., Qari, N., and Fihri, A. "High temperature corrosion resistant coatings for gas flare systems." Ceramic International 44, no.5 (2017): 5124-5130. https://doi.org/10.1016/i.ceramint.2017.12.114

[94] Talabi, S. I., Owolabi, O. B., Adebisi, J. A., and Yahaya, T. "Effect of welding variables on mechanical properties of low carbon steel welded joint." Advances in Production Engineering and Management 9, no. 4 (2014): 181-186. https://doi.org/10.14743/apem2014.4.186

[95] Tanimoto, H., Soga, Y., Takayanagi, Y., and Mizubayashi, H. "Dissolved-Oxygen-Induced Intensive Pitting Corrosion of Amorphous ZrCu Alloys in Thin NaCl Solutions." Materials Transaction 52, no. 7 (2011): 1402-1409. https://doi.org/10.2320/matertrans.M2010437

[96] Thavamani, P., Bhowmick, A. K., and Khastgir, D. "Effect of ageing on strength and wear of tank track pad compounds." Wear 170, no. 1 (2015): 25-32. https://doi.org/10.1016/0043-1648(93)90347-0

[97] Uzun, F., and Bilge, A. N. "The effect of caron content and submerged ard welding process on hardness of carbon steels." Journal for Foundations and Applications of Physics 4, no.1 (2017), 1-8.

[98] Votava, Jiř́. "Protection of welded joints against corrosion degradation." Acta Universitatis Agriculturae et Silviculturae Mendelianae Brunensis 61, no. 6 (2013): 1897-1904. https://doi.org/10.11118/actaun201361061897

[99] Wei, P. S. "The physics of weld bead defects." Welding processes (2012): 395-414.

[100] Xie, J., and A. Kar. "Laser welding of thin sheet steel with surface oxidation." WELDING JOURNAL-NEW YORK- 78 (1999): 343-s.

[101] Young, D. J., and J. Zhang. "Carbon corrosion of alloys at high temperature." Journal of the Southern African Institute of Mining and Metallurgy 113, no. 2 (2013): 149-154.

[102] Khattak, Muhammad Adil, Shahid Zaman, Mohd Nasir Tamin, Saeed Badshah, Syed Mushtaq, and Abdoulhdi Amhmad Borhana Omran. "Effect of Welding Phenomenon on the Microstructure and Mechanical Properties of Ferritic Stainless Steel-A Review." Journal of Advanced Research in Materials Science 32, no. 1 (2017): 13-31. 